\title{
Stocking rate and cow-calf production on sand sagebrush rangeland
}

\author{
ROBERT L. GILLEN AND PHILLIP L. SIMS
}

Authors are Rangeland Scientists, USDA-ARS, Southern Plains Range Research Station, 2000 18th Street, Woodward, Okla., 73801.

\begin{abstract}
Stocking rate is generally considered to be the most important management factor in sustainable grazing of Great Plains grasslands over management periods of 10 to 20 years or longer. Most studies to determine optimum stocking rates have compared only 2 or 3 discrete stocking rates. Our objective was to determine cow, calf, and economic performance on sand sagebrush (Artemisia filifolia Torr.) rangeland as a continuous function of stocking rate. Replicated stocking rates of $0.11,0.15$, and 0.22 head ha-1 were studied over an 8 -year period. Cow weight declined as stocking rate increased in drought years but was not affected by stocking rate in wetter years. Weaning percentage was not affected by stocking rate but variation within treatment groups was high. Calf birth weight and weaning weight both declined as stocking rate increased. Comparing 0.11 and 0.22 head ha ${ }^{-1}$, calf production cow ${ }^{-1}$ declined from 206 to $144 \mathrm{~kg} \mathrm{cow}^{-1}$ as stocking rate increased but calf production $\mathrm{ha}^{-1}$ increased from 22.6 to $31.7 \mathrm{~kg}$ calf $\mathrm{ha}^{-1}$. Net returns were maximized at $\$ 7.87 \mathrm{ha}^{-1}$ year $^{-1}$ at a stocking rate of $0.172 \mathrm{head} \mathrm{ha}^{-1}$, well within the range of experimental treatments. Net returns were within $5 \%$ of maximum between stocking rates of 0.156 and 0.183 head $\mathrm{ha}^{-1}$. The variability of all responses increased as stocking rate increased. Simulation indicated that improved livestock prices and increased animal productivity shifted the economic optimum stocking rate to higher levels, which would put more pressure on the conservation ethic of land managers.
\end{abstract}

Key Words: Artemisia filifolia, mixed prairie, Southern Plains, animal performance, optimum stocking rate

Stocking rate is generally considered to be the most important management factor in sustainable grazing of Great Plains grasslands over management periods of 10 to 20 years or longer. Numerous studies have reported the impact of stocking rate on livestock production. Weight gain of individual animals generally decreases while weight gain per unit land area increases as stocking rate increases (Vallentine 1990).

While some studies have used 2 or 4 levels of stocking rate (Heitschmidt et al. 1982, Willms et al. 1986), most studies on stocking rates have used 3 stocking rates, often qualitatively described as light, moderate, or heavy grazing. Quantitative

Contribution from the USDA-Agricultural Research Service. All programs and services of the U.S. Department of Agriculture are offered on a nondiscriminatory basis without regard to race, color, national origin, religion, sex, age, marital status, or handicap.

Manuscript accepted 11 Jan. 02.
Resumen

La carga animal generalmente es considerada el factor de manejo más importante del apacentamiento sustentable de los pastizales de las Grandes Planicies en periodos de manejo de 10 a 20 años o más. La mayoría de estudios para determinar la carga animal óptima han comparado solo 2 o 3 cargas animal discretas. Nuestro objetivo fue determinar el comportamiento económico de vacas y becerros en un pastizal de "Sand sagebrush" (Artemisia filifolia Torr.) Como una función continua de la carga animal. Durante un periodo de 8 años se estudiaron cargas animal repetidas de $0.11,0.15$, y 0.22 cabezas $h^{-1}$. En años secos el peso de la vaca disminuyó conforme se incrementó la carga animal, pero en años húmedos no fue afectado por la carga animal. El porcentaje de destete no fue afectado por la carga animal pero la variación dentro de los tratamientos fue alta. Los pesos al nacimiento $y$ al destete disminuyeron al aumentar la carga animal. Comparando las cargas de 0.11 y 0.22 cabezas ha ${ }^{-1}$ se observó que al aumentar la carga animal la producción de becerro vaca-1 disminuyó de 206 a $144 \mathrm{~kg} \mathrm{vaca}^{-1}$, pero la producción de becerro ha ${ }^{-1}$ se incrementó de 22.6 a $31.7 \mathrm{~kg}$ de becerro $\mathrm{ha}^{-1}$. Dentro del rango de tratamientos experimentales, los retornos netos se maximizaron a $\$ 7.87 \mathrm{ha}^{-1}$ año ${ }^{-1}$ con una carga animal de 0.172 cabezas ha $^{-1}$. Los retornos netos estuvieron dentro de 5\% del máximo entre las cargas animal de 0.156 y 0.183 cabezas ha ${ }^{-1}$. La variabilidad de todas las respuestas se incrementó al aumentar la carga animal. La simulación indicó que mejores precios del ganado y una mayor la productividad animal desviaron la carga animal óptima económica a niveles mas altos, los cuales pondrían mayor presión en la conservación ética de los manejadores de tierras.

stocking rates for each of these qualitative levels vary among regions depending on climate and soils. Moderate stocking rates are usually set at a level estimated to maintain populations of the dominant perennial forage grasses while light and heavy rates are set at some factor below and above moderate grazing. The common use of the qualitative descriptions of light, moderate, and heavy stocking does not take advantage of the continuous, quantitative nature of stocking rates. Development of continuous functions describing the impact of stocking rates on livestock production would allow inferences to be made at stocking rates other than those actually tested in the experiments and is a requirement for conclusive economic analyses (Bransby 1989).

The first objective of this study was to determine the impact of stocking rate as a continuous function on the biological performance of cows and calves grazing sand sagebrush rangeland in the Southern Great Plains. The second objective was to determine 
the response of net returns to stocking rate and to determine the stocking rate that maximized net returns per unit land area. Partial results of this study were first reported by Shoop and McIlvain (1971). This follow-up paper gives a more complete presentation of the results and uses a continuous function for stocking rate rather than only 2 discrete stocking rates.

\section{Materials and Methods}

\section{Experimental Pastures}

The study was conducted from 1952 through 1961 at the USDA-ARS Southern Plains Experimental Range in northwest Oklahoma $\left(36^{\circ} 35^{\prime} \mathrm{N}, 99^{\circ} 35^{\prime} \mathrm{W}\right.$, elev. 630 $\mathrm{m})$. The regional climate is continental. Average annual precipitation is $576 \mathrm{~mm}$ with $72 \%$ falling during the AprilSeptember growing season. Average monthly temperature is $2.3^{\circ} \mathrm{C}$ in January and $28^{\circ} \mathrm{C}$ in July. Minimum and maximum recorded temperatures are $-28^{\circ} \mathrm{C}$ and $45^{\circ} \mathrm{C}$.

Two distinct precipitation periods occurred during the study (Fig. 1). The first 4 years, 1953 to 1956 , were characterized by drought. Over this period, annual, winter, and summer precipitation averaged 65,45 , and $74 \%$ of the 60 -year average (1940 to 2000), respectively. The remaining 5 years received abundant precipitation. Annual and summer precipitation was 110 and $126 \%$ of the 60 -year average in these later years.

The landscape of the study area consists of undulating, stabilized sand dunes without well-defined drainage patterns. Soils were Pratt loamy fine sands (sandy, mixed thermic Psammentic Haplustalfs) on the lower slopes and more level areas and Tivoli fine sands (mixed, thermic Typic Ustipsamments) on the upper slopes of the dunes. The vegetation was sand sagebrush (Artemisia filifolia Torr.)-mixed prairie (Berg 1994). The understory was dominated by a mixture of tall, mid, and short warm-season grasses including sand bluestem [Andropogon halli Hack.], little bluestem [Schizachy-rium scoparium (Michx.) Nash], sand dropseed [Sporobolus cryptandrus (Torr.) Gray], and blue grama [Bouteloua gracilis (Willd. ex Kunth) Lag. ex Griffiths]. Western ragweed (Ambrosia psilostachya DC.), camphor weed [Heterotheca subaxillaris (Lam.) Britt. \& Rusby], and wooly plantain (Plantago patagonica Jacq.) were prominent forbs.

\section{Experimental Treatments}

This experiment was a continuation of a study initiated in 1942 (Sims and Gillen 1999). The experimental treatments were 3 stocking rates of yearling beef cattle. Stocking levels were 41, 53, and 82 animal-unit-days ha-1 (AUD ha-1) over a 320day grazing season. These stocking rates were selected to bracket the projected sustainable stocking rate for this vegetation type. In 1952 after 10 years of grazing, the livestock class was shifted from yearling cattle to cows and calves. Relative stocking rate treatments were maintained in the

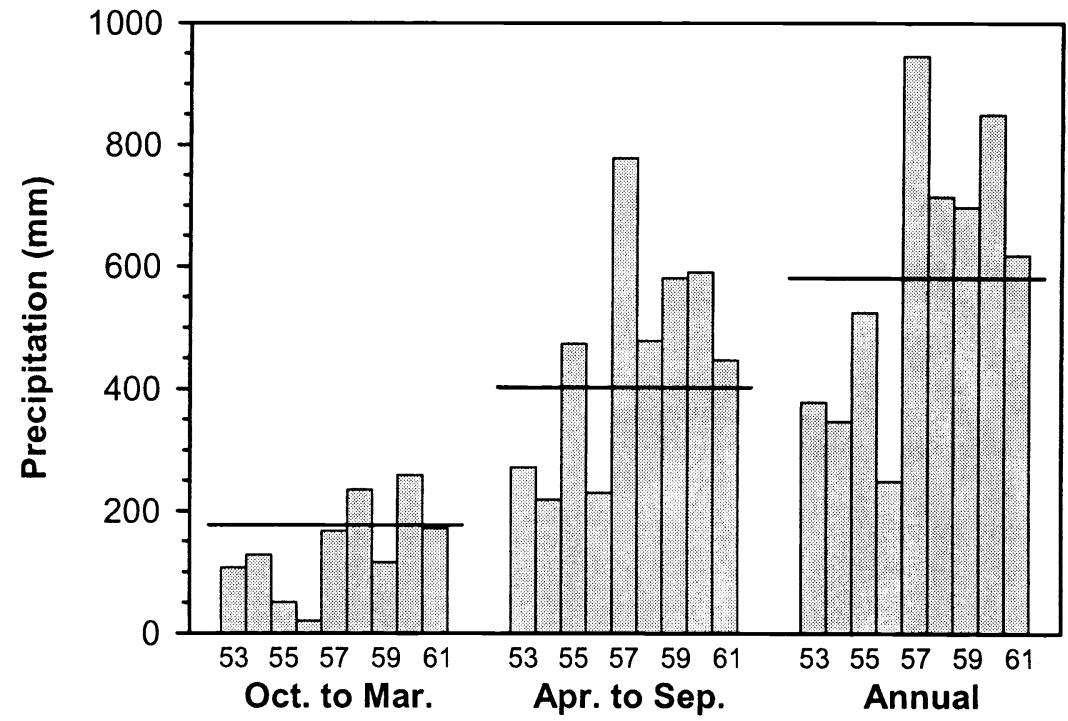

Fig. 1. Seasonal and annual precipitation $(\mathrm{mm})$ from 1953 to 1961 and the long-term averages (1940-1996, straight lines) for each season at the Southern Plains Experimental Range, Fort Supply, Okla. respective study pastures but the grazing season was expanded to year-long grazing. Stocking rates in this second phase of the experiment were 45, 60, and 87 animalunit-days $\mathrm{ha}^{-1}$, an average increase of $9 \%$ over the first phase.

A multi-step process was used to calculate the animal unit equivalents in the second phase of the study. First, winter cow weights were calculated by averaging October and April weights. Winter animalunit-days were then calculated as (winter weight ${ }^{0.75} / 454^{0.75}$ )* winter days (Vallentine 1990). Summer cow weights were calculated by averaging April weights and the weights from the following October. Summer animal-unit-days were then calculated as (summer weight ${ }^{0.75} / 454^{0.75}$ )* summer days*1.35. The factor 1.35 was used to account for greater forage intake when the cow was in lactation and had a grazing calf (Vallentine 1990). Winter and summer AUD's were then summed within a production year (October to October) to arrive at annual AUD's.

The expression of stocking rates as AUD ha ${ }^{-1}$ was necessary to compare stocking rates in the 2 phases of the study since the livestock class was different between phases. However, within a given livestock class it is often more practical to express stocking rates as head ha-1 (or ha head $^{-1}$ ) and economic analyses are conducted on a per head basis since that is the unit of production and sale. Throughout the remainder of this paper, stocking rates will be expressed as head ha ${ }^{-1}$. For conversion purposes, each cow-year averaged 408, 404, and 392 AUD for the 45, 60, and 87 AUD ha ${ }^{-1}$ treatments. This resulted in experimental treatments of $0.11,0.15$, and 0.22 head ha $^{-1}$.

The 3 stocking rate treatments were replicated 2 times for a total of 6 experimental pastures. Both herd size and pasture area were varied to produce the stocking rate treatments. Pastures ranged in size from 43 to 86 ha. All study pastures were contiguous. Herd sizes were initially either 12 or 14 head. Maturation of the cows and drought conditions in the first years of the cow-calf study caused the herd sizes to be reduced from the initial levels. The herds consisted of 10 or 12 head in 1954 and 1955, 8 head in 1956 and 1957, and 9 head from 1958 to 1961 . Stocking rates were adjusted over years in an effort to maintain a target forage utilization of $67 \%$ at the middle stocking rate at the end of each grazing year, approximately April 20 (Shoop and McIlvain 1971). Livestock numbers were adjusted in all of the treatments to maintain constant treatment ratios. 


\section{Livestock Management}

The cows used in this study were purchased as weaned heifer calves out of a single commercial herd of Hereford cattle in October 1951. The heifers were vaccinated for blackleg (Clostridia chauvoei), malignant edema (C. septicum), and brucellosis (Brucella abortus) at weaning. The heifers were first allocated to treatment groups on the basis of weight and condition in November 1951. Each group contained 18 heifers with an average weight of $202 \mathrm{~kg}$. During their first winter, the heifers were fed pelleted cottonseed meal containing $41 \%$ crude protein at a rate of $0.68 \mathrm{~kg}^{\text {head }}{ }^{-1} \mathrm{day}^{-1}$ from 17 November 1951 until 21 April 1952. They were also fed rolled sorghum grain [Sorghum bicolor (L.) Moench] from 11 December 1951 until 9 April 1952 at a rate of $0.9 \mathrm{~kg} \mathrm{head}^{-1} \mathrm{day}^{-1}$. The heifers were first bred from 10 June until 12 August 1952. Weight at first breeding averaged 302,298 , and $283 \mathrm{~kg}$ for the respective treatments. In November 1952, excess heifers were culled leaving either 12 or 14 heifers in each treatment group to begin the main body of the experiment.

The breeding season began on 15 May in 1953 and 30 April to 4 May the remaining years. The length of the breeding season ranged from 65 to 89 days with an average of 72 days. This resulted in calving seasons starting on 24 February in 1954 and 9 February to 13 February the remaining years. Breeding was done by natural service using Hereford bulls. Within stocking rate treatment, cows were gathered into a single herd during the breeding season and moved back and forth between replications at 1 or 2 week intervals. Grazing days were balanced between replications. A single bull was placed with each cow group. Bulls were rotated among all treatment groups every 2 to 3 days. One set of bulls was used from 1952 until 1957 when they were replaced by a new set for the remainder of the study. The bull:cow ratio ranged from 1:25 in 1952 to $1: 18$ in 1961 as cow stocking rates were reduced over the term of the study.

During the dormant forage period, cows were routinely fed supplemental protein in the form of pelleted cottonseed meal containing $41 \%$ crude protein. Rate of feeding was $0.91 \mathrm{~kg} \mathrm{head}^{-1} \mathrm{day}^{-1}$ from 1953 to 1955 and in 1960 and $0.68 \mathrm{~kg} \mathrm{head}^{-1}$ day $^{-1}$ for the other years. Average dates to start and end feeding were 18 November and 24 April, respectively, for a total feeding period of 162 days. There were 2 exceptions to the routine program and both were due to drought conditions and a shortage of standing forage. First, dormant season feeding began on 28 September for the 1955-56 production year. Second, pelleted cottonseed meal was fed at a rate of 0.91 $\mathrm{kg} \mathrm{head}^{-1}$ day $^{-1}$ from 11 June to 13 July 1956.

Cows were not routinely fed hay or other roughage. Cows were fed hay for 4 , 1 , and 9 days in the late winters of 1955 , 1957, and 1960, respectively, due to snow cover or cold temperatures. There were 2 major exceptions to this program. First, alfalfa (Medicago sativa L.) hay was fed at a rate of $2.3 \mathrm{~kg} \mathrm{head}^{-1} \mathrm{day}^{-1}$ to all cows from 2 March until 18 April 1953. This was just prior to and during their first calving season. Second, alfalfa hay was fed from 4 February to 29 April 1955 in response to drought conditions. The feeding rate was $0,2.3$, and $4.5 \mathrm{~kg} \mathrm{head}^{-1}$ day $^{-1}$ for cows stocked at $0.11,0.15$, and 0.22 head $\mathrm{ha}^{-1}$, respectively. The differential feeding rates were based on ocular assessments of pasture and livestock conditions. The cows received no other supplements except white block salt which was available free-choice at all times.

Cows remained in a given treatment group for the length of the study. Cows were only replaced if they had to be culled due to injury or if they died. Replacements were taken from cows of similar age and breeding maintained on reserve pastures stocked at the same rates as the treatment pastures.

Cows were weighed at monthly intervals year-round. Weights were taken in early morning after an overnight fast from forage and water. Cows were checked daily during the calving season. Calves were weighed and ear-tagged shortly after birth. At the first weigh date following the close of the calving season, usually in April, calves were hot-branded, dehorned, and vaccinated for blackleg and malignant edema. Male calves were castrated. Calves were then weighed at monthly intervals with the cows until weaning in mid October.

Dates chosen for analysis of cow weights were January (just prior to calving), April (just after calving), August (late growing season), and October (weaning). Calf performance was analyzed using birth and weaning weights.

\section{Statistical methods}

The general statistical model used in the analysis was a completely randomized, repeated measures design with stocking rate as the whole plot factor and year as the repeated factor. The stocking rate effect was tested with the pasture-withinstocking-rate error term. Year and stocking rate by year interactions were tested with the residual error term. If the stocking rate by year interaction was significant $(\mathrm{P}<0.05)$, analyses were conducted for individual years. Dependent variables were related to stocking rate (head ha ${ }^{-1}$ ) by linear regression within year using pasture means as observations. In addition, response data were averaged over years and related to stocking rate by linear regression. Dependent variables included cow weight, weaning percentage, calf birth weight, calf gain, calf weaning weight, calf weaned $\mathrm{cow}^{-1}$, and calf weaned $\mathrm{ha}^{-1}$. Weaning percentage data were transformed using the arcsin transformation before analysis.

To assess the variability of responses, we calculated standard deviations and coefficients of variation for all dependent variables over years. These standard deviations and coefficients of variation were than regressed against stocking rate.

An excess of heifers were bred in 1952 and then culled to arrive at the target group size within treatments. It is not clear from experimental records but it is likely that pregnancy was a criterion for culling since weaning percentage in 1953, the first year of calving, was $100 \%$ for all treatments. This may confound the calf production data from this first year so analysis of all treatment responses except cow weight were restricted to the years 1954 to 1961 .

\section{Economic methods}

The main objective of the economic analysis was to relate net economic returns to stocking rate. A spreadsheet model was developed to calculate net return ha ${ }^{-1}$ based on various input costs, livestock prices, and levels of calf production.

Input costs were entered as total variable costs per cow other than pasture or feed, pasture rental, and supplemental feed and hay. Total non-feed costs were set at $\$ 216$ cow $^{-1}$ based on data from the Standardized Performance Analysis of 253 cow herds in Texas from 1991 to 1999 (McGrann et al. 2000). Cost of supplemental feed and hay was based on actual feeding rate during the study and a cost of $\$ 0.22 \mathrm{~kg}^{-1}$ for supplement and $\$ 0.067 \mathrm{~kg}^{-1}$ for hay. Land costs were set at $\$ 16.70 \mathrm{ha}^{-1}$, the average rental rate for rangeland in this region in 1998 (Doye et al. 1999).

Livestock prices were actual prices from the Oklahoma City National Stockyards (Peel 1996a, 1996b) from the period 1986 to 1995 to encompass a complete price cycle. Prices were indexed to 1995 dollars using the Consumer Price Index. The relationship between calf weight and price $\mathrm{kg}^{-1}$ was determined for each year for both 
steers and heifers using linear regression. Calf weaning weight and weaning percentage over a continuous range of stocking rates were predicted using regression equations developed from the statistical analyses.

Economic returns were calculated as:

Gross income cow $^{-1}=$

$\left(\left(\left(\right.\right.\right.$ weaning weight $_{\mathrm{s}} *$ price $\left.\mathrm{kg}^{-1} \mathrm{~s}\right)+$

(weaning weight ${ }_{\mathrm{h}}^{*}$ price $\left.\mathrm{kg}^{-1} \mathrm{~h}\right)$ ) / 2 )

* (weaning \%/100),

where the subscripts $\mathrm{s}$ and $\mathrm{h}$ refer to steer and heifer, respectively. This assumes a 50:50 ratio between steers and heifers.

Input costs were calculated as:

Cost cow $^{-1}=$ variable cost cow ${ }^{-1}$

$+\left(\right.$ ha $\operatorname{cow}^{-1} *$ land cost ha $\left.{ }^{-1}\right)+$

(kg supplement cow $^{-1} *$ supplement

cost $\left.\mathrm{kg}^{-1}\right)+\left(\mathrm{kg}\right.$ hay $\operatorname{cow}^{-1} *$ hay cost

$\mathrm{kg}^{-1}$ ).

Net returns were calculated as:

Net return cow $^{-1}=$ Gross income $\operatorname{cow}^{-1}-$ cost $\operatorname{cow}^{-1}$.

Net return ha ${ }^{-1}=$ net return $\operatorname{cow}^{-1} / \mathrm{ha} \mathrm{cow}^{-1}$

Variability in calf prices and calf production were incorporated into the model using the @RISK simulation program ${ }^{1}$ (Palisade Software, Newfield, N.Y.). Regression parameters (intercepts and slope coefficients) for prices, weaning percentage, and weaning weight were assumed to be randomly distributed with standard deviations determined from the statistical analyses. Coefficients for weaning percentage and weaning weight were drawn randomly and independently from these distributions for each iteration of the model. Coefficients for steer and heifer prices were linked through the use of correlation coefficients. A different starting point in the cattle price cycle (1986 to 1995) was chosen randomly for each iteration. Once a starting point was determined, prices from consecutive years were used to maintain the general shape of the cycle. This process was repeated for 1,000 iterations. The model calculated net returns for each individual year and then averaged these net returns over the 8-year term of the study. The mean and standard deviation for net return $\mathrm{ha}^{-1}$ were then graphed by stocking rate.

An alternative analysis was performed in which price and calf production data were first averaged over the 8 years of the

${ }^{1}$ Names are necessary to report factually on available data, however, the USDA neither guarantees nor warrants the standard of the product, and the use of the name by USDA implies no approval of the product to the exclusion of others that may also be suitable.


Fig. 2. Average annual cow weight (kg) as affected by stocking rate and year. Regression models only shown for years with significant relationships $(P<0.05)$.

study. Single regression equations for price and production were fit to these data. Means and standard deviations for the regression coefficients were entered into the model. The simulation was then repeated for 1,000 iterations and results were graphed.

Finally, the economic model was analyzed for sensitivity to changes of $\pm 5,10$, or $15 \%$ in calf prices, variable cow costs, land costs, and calf production cow ${ }^{-1}$. Calf prices were varied by changing the intercepts of the regression equations but not the slope coefficients. Calf production was varied by changing the intercepts of the regression equations for weaning percentage or weaning weight. Changing equations for either variable, weaning percentage or weaning weight, gave equivalent results so we discuss changes in calf pro- 
Table 1. Weaned calf crop (\%) as affected by stocking rate (AUD ha $\left.{ }^{-1}\right)$ and year.

\begin{tabular}{|c|c|c|c|c|c|c|c|c|c|}
\hline Stocking rate & 1954 & 1955 & 1956 & 1957 & 1958 & 1959 & 1960 & 1961 & Average \\
\hline \multirow{2}{*}{$\begin{array}{l}\left(\text { AUD ha }^{-1}\right) \\
45\end{array}$} & & & & & $(10)$ & & & 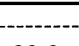 & 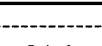 \\
\hline & $\begin{array}{l}76.5 \\
(9.2) 1\end{array}$ & $\begin{array}{l}95.0 \\
(7.1)\end{array}$ & $\begin{array}{l}80.0 \\
(0.0)\end{array}$ & $\begin{array}{l}94.0 \\
(8.5)\end{array}$ & $\begin{array}{l}83.5 \\
(7.8)\end{array}$ & $\begin{array}{l}83.5 \\
(7.8)\end{array}$ & $\begin{array}{l}70.0 \\
(0.0)\end{array}$ & $\begin{array}{c}89.0 \\
(0.0)\end{array}$ & $\begin{array}{l}84.6 \\
(8.8)\end{array}$ \\
\hline 60 & $\begin{array}{c}82.5 \\
(10.6)\end{array}$ & $\begin{array}{c}91.5 \\
(12.2)\end{array}$ & $\begin{array}{c}70.0 \\
(14.1)\end{array}$ & $\begin{array}{c}87.5 \\
(17.7)\end{array}$ & $\begin{array}{l}94.5 \\
(7.8)\end{array}$ & $\begin{array}{l}89.0 \\
(0.0)\end{array}$ & $\begin{array}{l}90.0 \\
(0.0)\end{array}$ & $\begin{array}{l}94.5 \\
(7.8)\end{array}$ & $\begin{array}{c}88.1 \\
(11.4)\end{array}$ \\
\hline 87 & $\begin{array}{c}69.0 \\
(15.6)\end{array}$ & $\begin{array}{c}74.0 \\
(22.7)\end{array}$ & $\begin{array}{l}55.0 \\
(7.1)\end{array}$ & $\begin{array}{c}87.5 \\
(17.7)\end{array}$ & $\begin{array}{c}89.0 \\
(15.6)\end{array}$ & $\begin{array}{l}89.0 \\
(0.0)\end{array}$ & $\begin{array}{l}60.0 \\
(0.0)\end{array}$ & $\begin{array}{l}72.5 \\
(7.8)\end{array}$ & $\begin{array}{c}77.1 \\
(14.4)\end{array}$ \\
\hline Average & $\begin{array}{c}76.02 \\
(11.2)\end{array}$ & $\begin{array}{c}86.8 \\
(15.6)\end{array}$ & $\begin{array}{c}70.0 \\
(11.0)\end{array}$ & $\begin{array}{c}89.7 \\
(12.3)\end{array}$ & $\begin{array}{l}89.0 \\
(9.8)\end{array}$ & $\begin{array}{l}89.0 \\
(7.0)\end{array}$ & $\begin{array}{c}78.3 \\
(11.7)\end{array}$ & $\begin{array}{l}87.2 \\
(8.3)\end{array}$ & \\
\hline
\end{tabular}

standard deviation

${ }^{2}$ LSD.05 for year $=12.3$; Stocking rate effect non-significant, $\mathrm{P}=0.11$; Stocking rate by Year effect non-significant, $\mathrm{P}$ $=0.44$.

duction without specifying whether they are due to changes in weaning percentage or weaning weight.

\section{Results and Discussion}

\section{Cow Weights}

The cows entered this study as yearling heifers in November 1951. At that time, body weights were 203, 202, and $202 \mathrm{~kg}$ for the $0.11,0.15$, and 0.22 head $\mathrm{ha}^{-1}$ stocking rate treatments, respectively. By April 1952, weights were different among treatments and inversely related to stocking rate (slope coefficient $-1.69, \mathrm{r}^{2}=0.85$, $\mathrm{P}<0.01)$. Annual average cow weights for the remainder of the study were affected by the interaction of stocking rate and year $(\mathrm{P}<0.01$, Fig. 2). Average cow weights declined as stocking rate increased for only the first 4 years (Fig. 2). Annual cow weights were similar among stocking rates by 1956 and were not affected by stocking rate through the end of the study (Fig. 2). Within the early years, treatment effects were largest in January and smallest in August and October. Over all treatments, the cows gained weight until they were 5 years old in 1956. Annual average weights fluctuated little the remainder of the study and ranged from 467 to $487 \mathrm{~kg}$.

Previous studies have generally reported a negative effect of stocking rate on cow weight (Lewis et al. 1956, Houston and Woodward 1966, Hughes 1974, Pearson and Whittaker 1974, Heitschmidt et al. 1982, Willms et al. 1986). In these studies, the reduction in cow weight between the heaviest and the lightest stocking rate has ranged from 11 to $45 \mathrm{~kg}$. Huston et al. (1993) reported no effect of stocking rate on annual average cow weights but as stocking rate increased cows lost more weight in winter and gained more weight in summer. Heitschmidt et al. (1990) found no difference between cow weights under moderate and heavy stocking rates over 6 years. In the current study, stocking rate reduced the weights of young cows in dry years but did not affect mature cows in years with above-average precipitation.

\section{Weaning Percentage}

The weaned calf crop was variable among stocking rates and years (Table 1). There was no detectable effect of stocking rate on weaning percentage and no stocking rate by year interaction. Year had a significant effect with the lowest weaning percentage, $70 \%$, in 1956 and the highest weaning percentage, $89.7 \%$, in 1957 (Table 1). In the Northern Great Plains, weaning percentage declined with stocking rate (Houston and Woodward 1966). Heitschmidt et al. (1982) and Winder et al. (2000) reported interactions of weaning percentage and year in that higher stocking rates only decreased weaning percentage in drought years. Other studies have reported no impact of stocking rate on weaning percentage (Hughes 1974, Heitschmidt et al. 1990, Pieper et al. 1991).

In the current study, standard deviations were often high within stocking rates (Table 1). This was a result of the low numbers of cows within treatment groups, 8 to 14 depending on treatment and year. One cow failing to wean a calf produced a large change in weaning percentage. The large within-group variation resulted in low statistical power for weaning percentage.

\section{Birth Weight}

Calf birth weights were lowest in 1954 with an average of $32.8 \mathrm{~kg}$ and highest in 1957 with an average of $36.2 \mathrm{~kg}$. Birth weight declined as stocking rate increased (Fig. 3, P = 0.01). Calves at the heaviest stocking rate of 0.22 head $^{-1}$ averaged $32.8 \mathrm{~kg}$ at birth while calves at the lightest

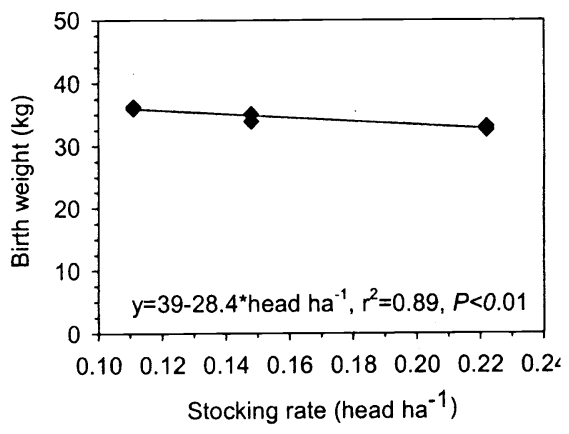

Fig. 3. Birth weight of calves (kg) as affected by stocking rate averaged over year. There was no stocking rate by year interaction $(P=0.42)$.

stocking rate of 0.11 head ha ${ }^{-1}$ averaged $35.9 \mathrm{~kg}$ at birth. There was no interaction between stocking rate and year $(\mathrm{P}=0.42)$.

The response of birth weight to stocking rate was mixed in other studies. In the Northern Great Plains, birth weights were not affected by stocking rates over 8 years (Woolfolk and Knapp 1949). In the next 9-year period of the same study, birth weights declined $4.1 \mathrm{~kg}$ from the lowest to the highest stocking rate (Houston and Woodward 1966). A similar pattern was reported from South Dakota where birth weights were not affected for the first 10 years (Johnson et al. 1951) but declined as stocking rate increased in the following 6 years. In both cases, the vegetation changed dramatically over time and the delayed response of calf birth weight may have been a reflection of the vegetation change. On southern forest range, Hughes (1974) found stocking rate did not affect birth weight.

\section{Weaning Weight}

Calf weaning weight, averaged over all stocking rates, ranged from a low of 172 $\mathrm{kg}$ in 1954 to highs of $235 \mathrm{~kg}$ in both 1957 and 1958. Weaning weight was affected by the interaction of stocking rate and year ( $P=0.01$, Fig. 4). In 6 of 8 years, weaning weight declined as stocking rate increased. In most previous studies, calf weaning weights have consistently declined as stocking rates increased (Woolfolk and Knapp 1949, Johnson et al. 1951, Lewis et al. 1956, Houston and Woodward 1966, Hughes 1974, Pearson and Whitaker 1974, Heitschmidt et al. 1982, Pieper et al. 1991). However, Heitschmidt et al. (1990) and Huston et al. (1993) reported no effect of stocking rate on calf weaning weight.

The negative effect of stocking rate was more pronounced in the drought years, 1954 to 1956 (Shoop and McIlvain 1971). 

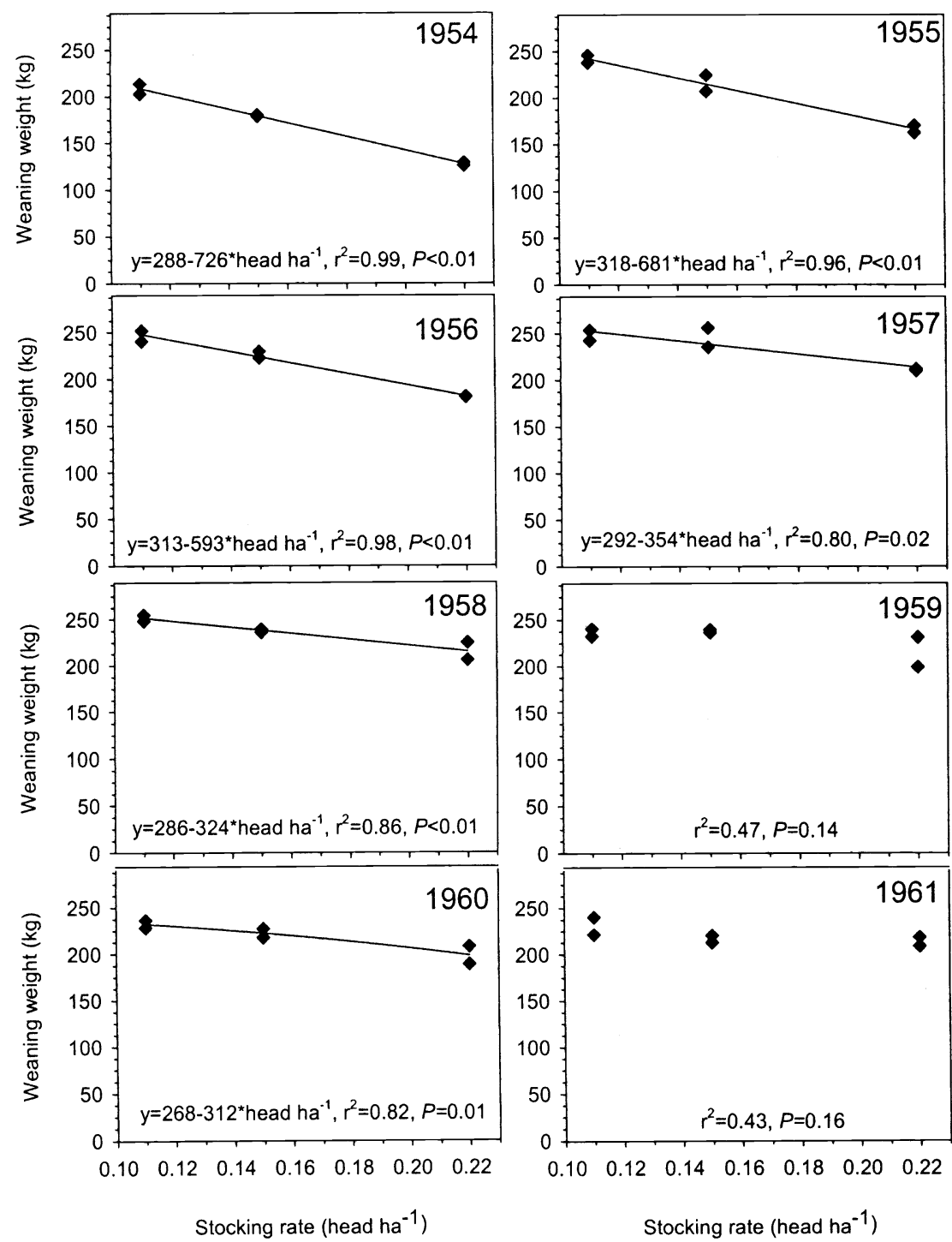

Fig. 4. Weaning weight of calves $(\mathrm{kg})$ as affected by stocking rate and year. Regression models only shown for years with significant relationships $(\mathrm{P}<0.05)$.

The average slope coefficient relating weaning weight and stocking rate (head $\mathrm{ha}^{-1}$ ) in non-drought years was -268.8 but in drought years this coefficient was $-667.0(\mathrm{P}=0.01$ for non-drought versus drought years). In non-drought years, the difference in weaning weight between a moderate stocking rate of 0.15 head $\mathrm{ha}^{-1}$ and a heavy stocking rate of 0.22 head $^{-1}{ }^{-1}$ was $20 \mathrm{~kg}$. In drought years, this same difference was $60 \mathrm{~kg}$. Alternatively, drought reduced weaning weight by $23 \mathrm{~kg}$ at 0.15 head ha ${ }^{-1}$ but drought reduced weaning weight by $53 \mathrm{~kg}$ at $0.22 \mathrm{head} \mathrm{ha}^{-1}$.

Calf weaning weight is a function of both birth weight and rate of gain. The majority of the decline in weaning weight in this study was attributable to decreased rate of gain because birth weights only varied by $3 \mathrm{~kg}$ from between stocking rates of 0.11 head ha $^{-1}$ and 0.22 head ha $^{-1}$ and age at weaning was similar among treatments.

\section{Calf Production}

Calf production per cow was affected by year $(\mathrm{P}<0.01)$ and ranged from $132 \mathrm{~kg}$ cow $^{-1}$ in 1954 to $210 \mathrm{~kg} \mathrm{cow}^{-1}$ in 1957 , when averaged over stocking rates. Calf production per cow declined as stocking rate increased $(P=0.03$, Fig. 5). There was no interaction between stocking rate and year $(P=0.25)$. Houston and Woodward (1966) reported that calf production declined from 174 to $98 \mathrm{~kg} \mathrm{cow}^{-1}$ as stocking rate increased from 0.048 head $\mathrm{ha}^{-1}$ to 0.084 head ha $^{-1}$. The effect of stock-

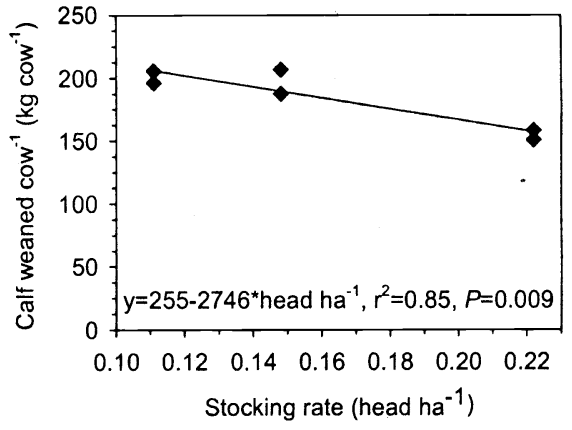

Fig. 5. Calf production $\operatorname{cow}^{-1}\left(\mathrm{~kg} \mathrm{cow}^{-1}\right)$ as affected by stocking rate averaged over year. There was no stocking rate by year interaction $(P=0.25)$.

ing rate on calf production cow per cow is not always this large. Heitschmidt et al. (1982) found that calf production declined an average of only $7 \mathrm{~kg} \mathrm{cow}^{-1}$ as stocking rate increased from 0.132 to 0.196 head $\mathrm{ha}^{-1}$ and the difference between stocking rates was present in only 4 of 15 years. Later studies at the same location found no difference in calf production cow per cow (Heitschmidt et al. 1990). Johnson et al. (1951) also reported no difference among stocking rates over the first 8 years of a long-term study.

Calf production per area fluctuated over years from a low of $22.5 \mathrm{~kg} \mathrm{ha}^{-1}$ in 1954 to a high of $31.0 \mathrm{~kg} \mathrm{ha}^{-1}$ in 1958. Production over all stocking rates and years was 26.9 $\mathrm{kg} \mathrm{ha}^{-1}$. Production per area was affected by the interaction of stocking rate and year $(\mathrm{P}=0.05$, Fig. 6). Production per area increased as stocking rate increased in 6 of 8 years. Calf production per area was not affected by stocking rate in 1954 and 1956, the driest years of the study. Maximum production per area was achieved within the range of experimental stocking rates in only one year, 1960.

The reduction in calf production per cow was more than offset by the increased number of cows with increasing stocking rate. As a result, calf production $\mathrm{ha}^{-1}$ increased as stocking rate increased even though calf production $\mathrm{cow}^{-1}$ decreased, a response demonstrated in previous work on cow-calf production (Houston and Woodward 1966, Heitschmidt et al. 1982 1990, Willms et al. 1986, Pieper et al. 1991) and with the established theory relating livestock production and stocking rate (Vallentine 1990).

\section{Variability}

Relative annual variability of the biological responses, as expressed by the coeffi- 

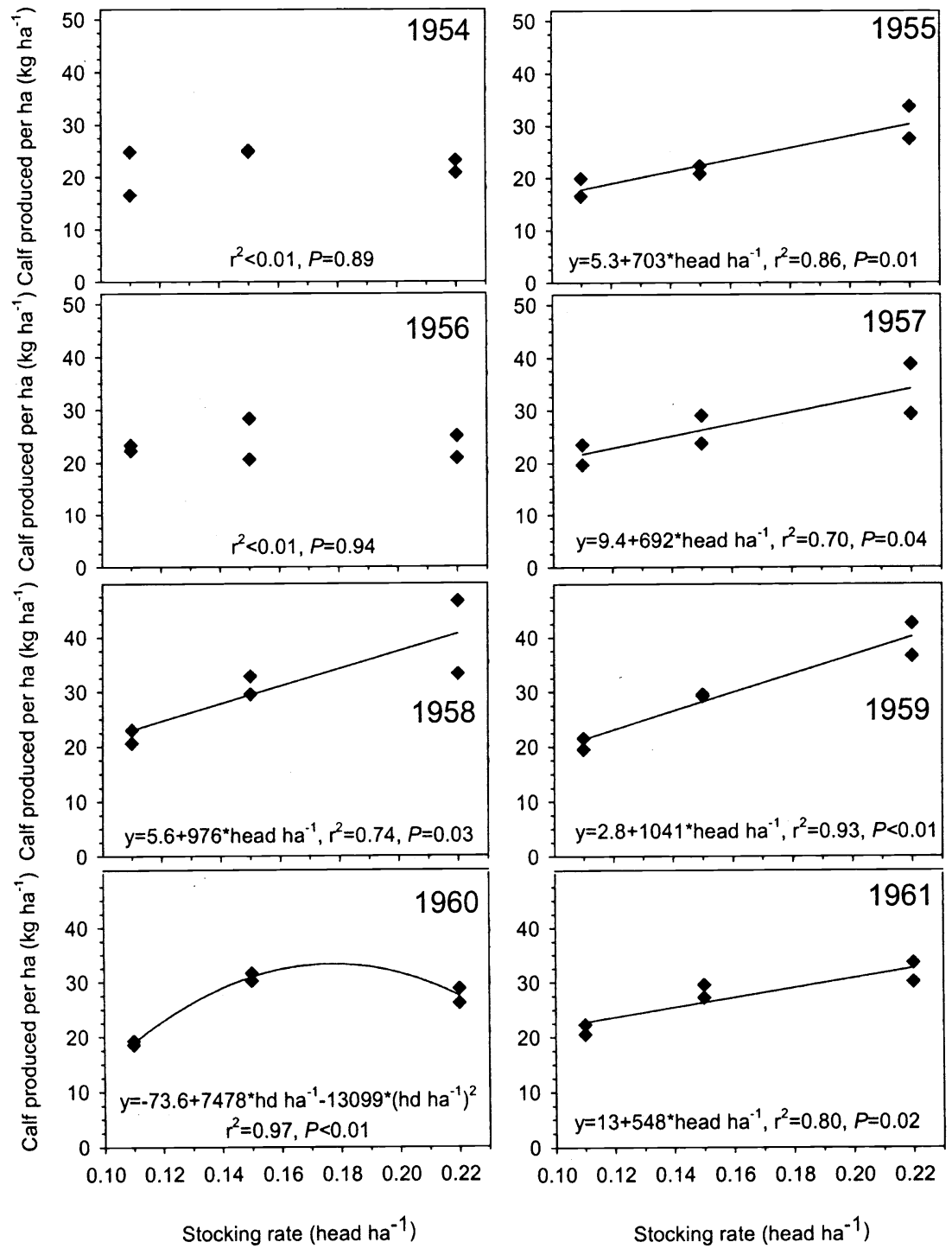

Fig. 6. Calf production ha $\left.\mathrm{ha} \mathrm{ha}^{-1}\right)$ as affected by stocking rate and year.

cient of variation, generally increased as stocking rate increased (Fig. 7). Calf birth weight was the least variable of all responses while calf production per cow showed the greatest variability. Previous work has also reported greater variation in livestock production as stocking rate increased. Much of this variation was a result of forced reductions at higher stocking rates due to drought (Johnson et al. 1951, Houston and Woodward 1966, Heitschmidt et al. 1990, Pieper et al.
1991). The current results indicate increased variability as stocking rates increase even when destocking is not required. Relative variability in gains of yearling cattle also increased as stocking rate increased during the first 10 years of this study (Sims and Gillen 1999).

\section{Economic Responses}

Within the conditions of this study, net returns were maximized at $\$ 7.87 \mathrm{ha}^{-1}$ year $^{-1}$ at a stocking rate of 0.172 head ha $^{-1}$ (Fig. $8 \mathrm{~A})$. The curve relating net returns and stocking rate was broad. Returns were within $5 \%$ of maximum at stocking rates between 0.156 and 0.183 head $\mathrm{ha}^{-1}$. The width of the $95 \%$ confidence band increased as stocking rate increased indicating greater variability in net returns at higher stocking rates. Previous studies have also reported greater income variability as stocking rates increase (Shoop and McIlvain 1971, Whitson et al. 1982, Riechers et al. 1989, Foran and Smith 1991). Based on this analysis, there is no economic incentive to graze at a stocking rate greater than 0.172 head ha $^{-1}$ (5.8 ha head $\left.^{-1}\right)$. Grazing at a rate below 0.172 head ha $^{-1}$ would sacrifice little net income but would reduce variability of annual returns, reduce impact on the vegetation resource, and leave greater amounts of residual vegetation for site protection and wildlife cover.

Shoop and McIlvain (1971) found higher net returns at moderate stocking, 0.15 head $\mathrm{ha}^{-1}$, compared to heavy stocking, 0.22 head ha $^{-1}$. The current analysis of the same data found similar results but the maximum net return occurred between the moderate and heavy stocking rates, as defined in the experiment. This illustrates the interpretative value of fitting quantitative response curves rather than comparing discrete stocking rates.

Net returns based on averaged data were maximized at $\$ 7.57 \mathrm{ha}^{-1}$ year ${ }^{-1}$ at a stocking rate of 0.158 head ha $^{-1}$ (Fig. 8B). Both of these numbers are lower than the respective amounts based on year-by-year

Table 2. Effect of changes in various inputs on maximum net returns $\mathrm{ha}^{-1}$ and the stocking rate that produces those returns.

\begin{tabular}{|c|c|c|c|c|c|c|c|c|}
\hline \multirow[b]{2}{*}{ Change } & \multicolumn{2}{|c|}{ Cattle prices } & \multicolumn{2}{|c|}{$\begin{array}{l}\text { Cow costs } \\
\text { (non-feed) }\end{array}$} & \multicolumn{2}{|c|}{ Land costs } & \multicolumn{2}{|c|}{ Calf production cow ${ }^{-1}$} \\
\hline & Net return & Stocking rate & Net return & Stocking rate & Net return & Stocking rate & Net return & Stocking rate \\
\hline$\overline{(\%)}$ & $\left(\$ \mathrm{ha}^{-1}\right)$ & $\left(\right.$ head ha $\left.{ }^{-1}\right)$ & $\left(\$ \mathrm{ha}^{-1}\right)$ & $\left(\right.$ head ha $\left.{ }^{-1}\right)$ & $\left(\$ \mathrm{ha}^{-1}\right)$ & (head ha ${ }^{-1}$ ) & $\left(\$ \mathrm{ha}^{-1}\right)$ & (head ha ${ }^{-1}$ ) \\
\hline-15 & $-\$ 6.97$ & 0.152 & $\$ 13.57$ & 0.182 & $\$ 10.35$ & 0.172 & $-\$ .86$ & 0.152 \\
\hline-10 & -2.13 & 0.161 & 11.64 & 0.179 & 9.51 & 0.172 & 2.10 & 0.159 \\
\hline-5 & 2.84 & 0.167 & 9.71 & 0.175 & 8.67 & 0.172 & 5.02 & 0.167 \\
\hline 0 & 7.91 & 0.172 & 7.91 & 0.172 & 7.91 & 0.172 & 7.91 & 0.172 \\
\hline 5 & 13.10 & 0.175 & 6.08 & 0.169 & 7.02 & 0.172 & 10.60 & 0.175 \\
\hline 10 & 18.24 & 0.179 & 4.20 & 0.167 & 6.23 & 0.172 & 13.24 & 0.182 \\
\hline 15 & 23.45 & 0.182 & 2.45 & 0.162 & 5.31 & 0.172 & 15.69 & 0.182 \\
\hline
\end{tabular}



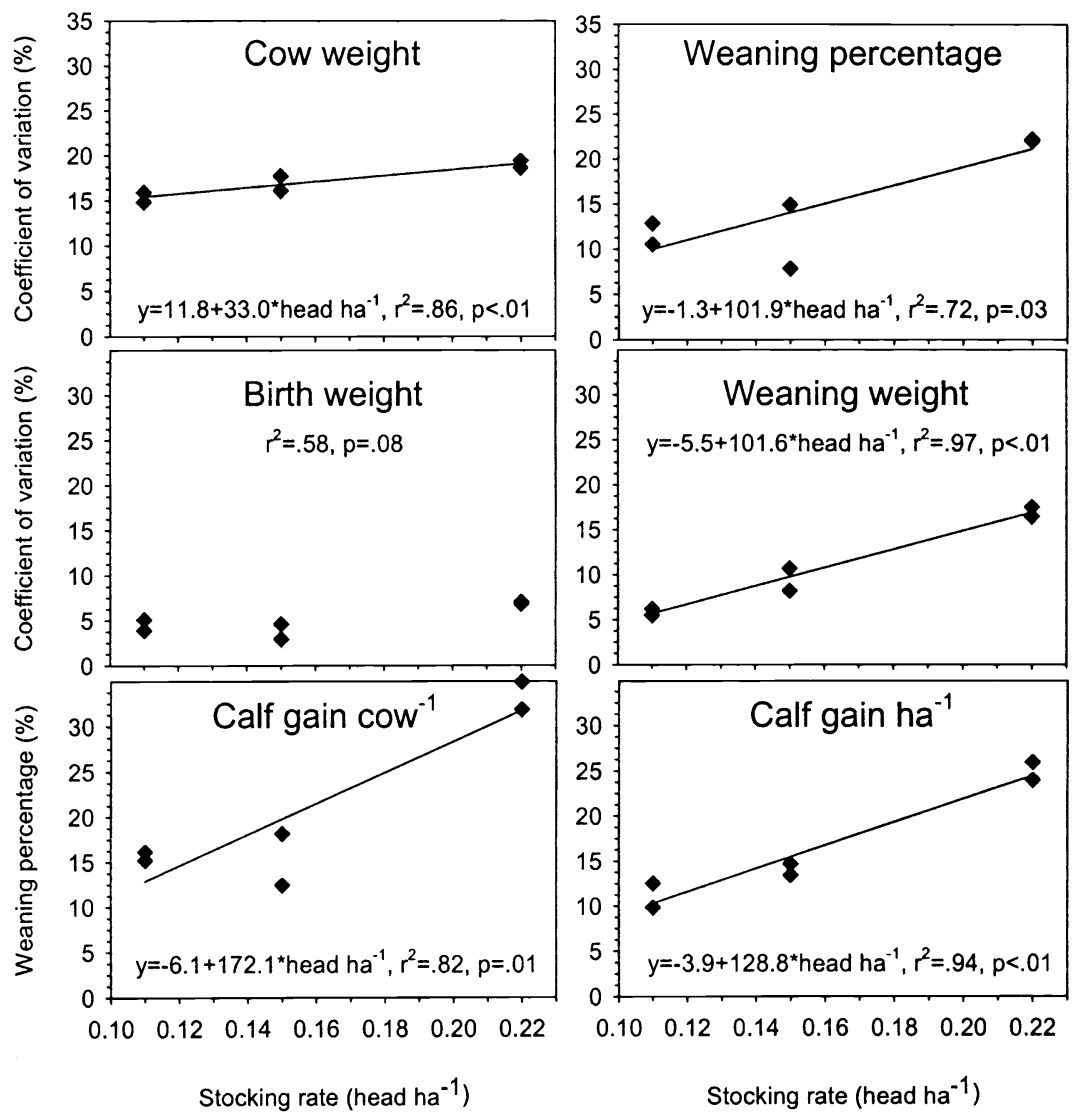

Fig. 7. Coefficient of variation of livestock responses over years as affected by stocking rate. Regression models only shown for years with significant relationships $(P<0.05)$.

calculations. Returns were within $5 \%$ of maximum at stocking rates between 0.140 and 0.179 head ha $^{-1}$. This translates to a rather broad range of 7.1 to 5.6 ha head $^{-1}$ and encompasses the moderate stocking rate of Shoop and McIlvain (1971). Variability was greater for averaged data than for year-by-year calculations although variability increased as stocking rate increased for both methods. While actual returns and optimum stocking rates vary slightly, conclusions drawn from the use of year-by-year calculations or averaged data are similar. The use of averaged data is more conservative and simplifies the analysis at the expense of some annual detail.

Net returns and the optimum stocking rate were sensitive to changes in inputs to the economic model (Table 2.). As base cattle prices increased, net returns increased and the optimum stocking rate increased. Decreases in non-feed cow costs also increased net returns and the optimum stocking rate. Other authors have also reported that as the ratio between costs and prices decreases, the economic optimum stocking rate increases (Quigley et al. 1984, Wilson and MacLeod 1991).
Increasing the amount of calf weaned per cow (either by increasing weaning percentage or weaning weights) increased net returns and the optimum stocking rate. As the production environment became more favorable (cattle prices increased, nonfeed cow costs decreased, or calf production increased), net returns increased and the optimum stocking rate also increased.

These results indicate that improved livestock markets and management practices that increase individual animal performance (such as supplementation) favor higher stocking rates. As market structures or animal performance improve, net returns would increase at all stocking rates but returns would be maximized at higher stocking rates. Wilson and MacLeod (1991) reported similar conclusions. However, these theoretical increases in net returns may not be attainable if stocking rates are already at the maximum sustainable level from an ecological perspective. One exception to this trend is the cost of land. As land costs decreased, net returns increased but the optimum stocking rate remained constant.
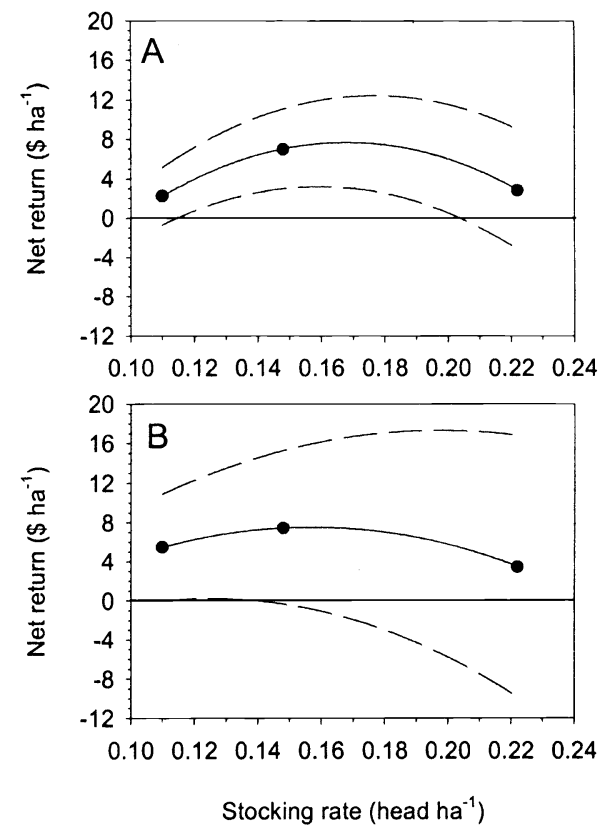

Fig. 8. Economic returns as affected by stocking rate. A) Net returns ( $\$$ ha $^{-1}$ year $^{-1}$ ) determined from year-by-year livestock performance and prices. B) Net returns determined from average livestock performance over 8 years and average prices. Both results based on 1000 iterations of an economic model. Solid circles indicate stocking rate treatments used in the experiment.

\section{Conclusions}

As stocking rates increased, gains of individual animals generally decreased but total gain ha ${ }^{-1}$ increased. However, the effects of stocking rate were dependent on weather. The negative effects of stocking rate on cow and calf performance were more pronounced during drought years. In other years, favorable weather conditions either reduced or eliminated the influence of stocking rate. Increasing stocking rate also increased the variability of livestock and economic performance.

The stocking rate that generated maximum net returns did not produce maximum calf production cow $^{-1}$ or maximum calf production $\mathrm{ha}^{-1}$. This is in agreement with basic stocking rate (Wilson and MacLeod 1991) and economic theory (Torell et al. 1991). The economic optimum stocking rate in this analysis was higher than that originally determined by Shoop and Mcllvain (1971) but the earlier study compared only 2 discrete stocking rates rather than a continuous range of stocking rates. A stocking rate of 0.172 head $\mathrm{ha}^{-1}$ appears to be sustainable in the 
medium to long term. There was no indication of a downward trend in livestock performance after 20 years of study, a criterion that has been suggested as a measure of overgrazing (Wilson and MacLeod 1991).

\section{Literature Cited}

Berg, W.A. 1994. Sand sagebrush - mixed prairie, p. 99. In: T. N. Shiflet (ed.), Rangeland Cover Types of the United States. Soc. Range Manage., Denver, Colo.

Bransby, D.I. 1989. Justification for grazing intensity experiments: economic analysis. J. Range Manage. 42:425-430.

Doye, D.G., D. Kletke, and B.L. Fischer. 1999. Oklahoma pasture rental rates: 199899. Okla. Coop. Ext. Serv. Current Report CR-216, Stillwater, Okla.

Foran, B.D. and D.M. Stafford Smith. 1991. Risk, biology and drought management strategies for cattle stations in central Australia. J. Environ. Manage. 33:17-33.

Heitschmidt, R.K., M.M. Kothmann, and W.J. Rawlins. 1982. Cow-calf response to stocking rates, grazing systems, and winter supplementation at the Texas Experimental Ranch. J. Range Manage. 35:204-210.

Heitschmidt, R.K., J.R. Conner, S.K. Canon, W.E. Pinchak, J.W. Walker, and S.L. Dowhower. 1990. Cow/calf production and economic returns from yearlong continuous, deferred rotation and rotational grazing treatments. J. Prod. Agr. 3:92-99.

Hughes, R.H. 1974. Management and utilization of pineland threeawn range in south Florida. J. Range Manage. 27:186-192.
Houston, W.R. and R.R. Woodward. 1966. Effects of stocking rates on range vegetation and beef cattle production in the northern Great Plains. USDA Tech. Bull. 1357.

Huston, J.E., P.V. Thompson, and C.A. Taylor, Jr. 1993. Combined effects of stocking rate and supplemental feeding level on adult beef cows grazing native rangeland in Texas. J. Anim. Sci. 71:3458-3465.

Johnson, L.E., L.R. Albee, R.O. Smith, and A.L. Moxon. 1951. Cows, calves, and grass. S. Dak. Agr. Exp. Sta. Bull. 412. Brookings, S. Dak.

Lewis, J.K, G.M. Van Dyne, L.R. Albee, and F.W. Whetzal. 1956. Intensity of grazing: its effect on livestock and forage production. $S$. Dak. Agr. Exp. Sta. Bull. 459. Brookings, S. Dak.

McGrann, J.M., L. Falconer, and J. Parker. 2000. Cost effective decisions needed: cowcalf SPA results for Texas - 1991-1999. Dept. Agr. Econ., Texas A\&M Univ./Tex. Agr. Ext. Serv., http://agecoext.tamu.edu/spa. (accessed Dec. 2000).

Peel, D. 1996a. Oklahoma City stocker and feeder heifer prices, 1975-1995. Okla. Coop. Ext. Serv. Current Report CR-545. Stillwater, Okla.

Peel, D. 1996b. Oklahoma City stocker and feeder steer prices, 1975-1995. Okla. Coop. Ext. Serv. Current Report CR-544. Stillwater, Okla.

Pearson, H.A. and L.B. Whitaker. 1974. Forage and cattle responses to different grazing intensities on southern pine ridge. J. Range Manage. 27:444-446.

Pieper, R.D., E.E. Parker, G.B. Donart, J.D. Wallace, and J.D. Wright. 1991. Cattle and vegetation response to four-pasture rotation and continuous grazing systems. N.M. Agr. Exp. Sta. Bull. 756. Las Cruces, N.M.
Quigley, T.M., J.M. Skovlin, and J.P. Workman. 1984. An economic analysis of two systems and three levels of grazing on ponderosa pine-bunchgrass range. J. Range Manage. 37:309-312.

Riechers, R.K, J.R. Conner, and R.K. Heitschmidt. 1989. Economic consequences of alternative stocking rate adjustment tactics: a simulation approach. J. Range Manage. 42:165-171.

Shoop, M.C. and E.H. McIlvain. 1971. Why some cattlemen overgraze-and some don't J. Range Manage. 24:252-257.

Sims, P.L. and R.L. Gillen. 1999. Rangeland and steer responses to grazing in the Southern Plains. J. Range Manage. 52:651-660.

Torell, L.A., K.S. Lyon, and E.B. Godfrey. 1991. Long-run versus short-run planning horizons and the rangeland stocking rate decision. Amer. J. Agr. Econ. 73:795-807.

Vallentine, J.F. 1990. Grazing management. Academic Press, Inc. San Diego, Calif.

Wilson, A.D. and N.D. MacLeod. 1991. Overgrazing: present or absent? J. Range Manage. 44:475-482.

Winder, J A., C.C. Bailey, M. Thomas, and J. Holechek. 2000. Breed and stocking rate effects on Chihuahuan Desert cattle production. J. Range Manage. 1:32-38.

Whitson, R.E., R.K. Heitschmidt, M.M. Kothmann, and G.K. Lundgren. 1982. The impact of grazing systems on the magnitude and stability of ranch income in the Rolling Plains of Texas. J. Range Manage. 35:526-532.

Willms, W.D., S. Smoliak, and G.B. Schaalje. 1986. Cattle weight gains in relation to stocking rate on rough fescue grassland. J. Range Manage. 39:182-186.

Woolfolk, E.J. and B. Knapp, Jr. 1949. Weight and gain of range calves as affected by rate of stocking. Mont. Agr. Exp. Sta. Bull. 463. Billings, Mont. 